\title{
Metazoan Parasite Infracommunities in Five Sciaenids from the Central Peruvian Coast
}

\author{
Marcelo E Oliva/ ${ }^{+}$, José L Luque* \\ Instituto de Investigaciones Oceanológicas, FAREMAR, Universidad de Antofagasta, Casilla Postal 170, \\ Antofagasta, Chile *Departamento de Parasitologia Animal, Universidade Federal Rural do Rio de Janeiro, \\ Caixa Postal 74508, 23851-970 Seropédica, RJ, Brasil
}

Parasitological analysis of 237 Menticirrhus ophicephalus, 124 Paralonchurus peruanus, 249 Sciaena deliciosa, 50 Sciaena fasciata and 308 Stellifer minor from Callao (Perú) yielded 37 species of metazoan parasites (14 Monogenea, 11 Copepoda, 4 Nematoda, 3 Acanthocephala, 1 Digenea, 1 Aspidobothrea, 1 Eucestoda, 1 Isopoda and 1 Hirudinea). Only one species, the copepoda Bomolochus peruensis, was common to all five hosts. The majority of the components of the infracommunities analyzed are ectoparasites. The Brillouin index $(H)$ and evenness $\left(J^{\prime}\right)$ were applied to the fully sampled metazoan parasite infracommunities. High values of prevalence and mean abundance of infection are associated to the polyonchoinean monogeneans; the low values of J' reinforce the strong dominance of this group in the studied communities. The paucity of the endoparasite fauna may be a consequence of the unstable environment due to an upwelling system, aperiodically affected by the El Niño Southern Oscillation phenomena.

Key words: marine sciaenids - parasite community - diversity - Peruvian coast

The structure of the metazoan parasite community of fish, like that of other vertebrates and invertebrates, has recently attracted some attention. The first definition of a parasitic community was given by Cloutman (1975) who said that it is "the complex of individuals belonging to the different parasite species inhabiting a host". Studies focusing on the structure of parasite communities in marine fish, in terms of diversity, are scarce. There are few papers that consider the parasite community in fishes in terms of both endo and ectoparasites (Thoney 1991, Luque \& Oliva 1993a, Campos \& Carbonell 1994, Luque 1994, Molloy et al. 1995, Luque et al. 1996, Groenewold et al. 1996, Kennedy \& Pojmanska 1996, Takemoto et al. 1996) and only one (Campos \& Carbonell 1994) analyzed the community structure in terms of diversity. The goal of this paper is to develop an analysis of community structure in five sciaenids from the Peruvian coast. This is the first paper that analyzes five related host species in this manner.

\section{MATERIALS AND METHODS}

Nine hundred and sixty-eight sciaenids (237 Menticirrhus ophicephalus, 124 Paralonchurus peruanus, 249 Sciaena deliciosa, 50 Sciaena fasciata and 308 Stellifer minor) were examined

\footnotetext{
${ }^{+}$Corresponding author. Fax: $+56-55-247542$. E-mail: meoliva@reuna.cl

Received 1 November 1996

Accepted 28 November 1997
}

for metazoan parasites. Fish were obtained from the fish market of Chorrillos and Callao $\left(12^{\circ} \mathrm{S}\right)$, during 1987-1988. Communitary descriptors for $P$. peruanus, S. minor and M. ophicephalus have been described previously by Oliva et al. (1990), Luque and Oliva (1993a), and Luque (1994). The same methodology was applied to the remaining two species. Because of the non-normal distribution of the number of parasitic species in each host fish, the Kruskall-Wallis test (and the corresponding non-parametric a posteriori Tukey test) was run to determine whether significant differences among the host parasite species are detectable. Diversity $(\mathrm{H})$ and evenness (J') were calculated only for those fish with more than one parasitic species (diversity not defined for $\mathrm{k}=1$ ) using the Brillouin's diversity index $(\mathrm{H})$ because each fish analyzed corresponds to a fully censused community (Zar 1984). The statistical analysis follows Wilkinson (1990). Type specimens and voucher number are in a series of taxonomic papers, that are the base for this paper.

\section{RESULTS}

Thirty-seven species of parasites were obtained from the fish hosts. Table I shows the parasites found in each host species, their location and parasitological indices. The copepod Bomolochus peruensis Luque and Bruno, 1990 was the only parasite present in all the five host species. The monogenean Cynoscionicola americana Tantaléan, Martinez and Escalante, 1987 and the generalist digenea Helicometra fasciata (Rudolphi, 1819) were found in four host species. 


\section{TABLE I}

Parasites of sciaenids from central Perú, location in the host, prevalence and mean intensity

\begin{tabular}{cccccccccccc}
\hline & $\begin{array}{c}\text { Sciaena } \\
\text { fasciata }\end{array}$ & $\begin{array}{c}\text { Paralonchurus } \\
\text { peruanus }\end{array}$ & $\begin{array}{c}\text { Stellifer } \\
\text { minor }\end{array}$ & $\begin{array}{c}\text { Menticirrhus } \\
\text { ophicephalus }\end{array}$ & $\begin{array}{c}\text { Sciaena } \\
\text { deliciosa }\end{array}$ \\
\hline Loc & P & MI & P & MI & P & MI & P & MI & P & MI \\
\hline
\end{tabular}

\section{MONOGENEA}

Cynoscionicola sciaenae

Cynoscionicola americana

Diplectanidae sp. 1

Diplectanidae sp. 2

Diplectanidae sp. 3

Hargicotyle magna

Hargicotyle menticirrhi

Hargicotyle paralonchuri

Hargicotyle sciaenae

Pseudohaliotrema paralonchuri

Pedocotyle annakohni

Pedocotyle bravoi

Rhamnocercoides menticirrhi

Rhamnocercus sp.

ASPIDOBOTHREA
Lobatostoma veranoi

DIGENEA

Helicometra fasciata

EUCESTODA

Lacistorhynchus dollfusi

\section{NEMATODA}

Ascarophis sp.

Camallanus sp.

Dichelyne amaruincai

Procamallanus sp.

\section{ACANTHOCEPHALA}

Corynosoma australis

Rhadinorhynchus sp.

Tegorhynchus sp.

\section{COPEPODA}

Bomolochus peruensis

Caligus callaoensis

Caligus quadratus

Clavellopsis sp.

Clavellotis dilatata

Lernanthropus huamani

Lernanthropus paralonchuri

Neobrachiella fasciata

Neobrachiella chevreuxii

Neobrachiella menticirrhi

Neobrachiella oralis

\section{ISOPODA}

Cymothoidae gen sp.

$\begin{array}{rrr}\mathrm{G} & & \\ \mathrm{G} & 78 & 5 \\ \mathrm{G} & 100 & 289 \\ \mathrm{G} & 92 & 141 \\ \mathrm{G} & & \\ \mathrm{G} \mathrm{M} & 42 & 1.4 \\ \mathrm{G} \mathrm{M} & & \\ \mathrm{G} \mathrm{M} & & \\ \mathrm{G} \mathrm{M} & & \\ \mathrm{G} & & \\ \mathrm{G} & & \\ \mathrm{G} & & \\ \mathrm{G} & & \\ \mathrm{G} & & \end{array}$

I

I $2 \quad 2$

$\begin{array}{lrr}\mathrm{CC} & 44 & 52.8\end{array}$

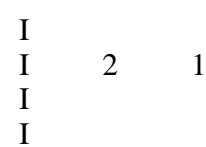

$\mathrm{CC}$
$\mathrm{I}$
$\mathrm{I}$

$\begin{array}{llll}0.8 & 1 & 0.3 & 1 \\ & & 0.9 & 1\end{array}$

$46.0 \quad 5.1$

$\begin{array}{llll}65.9 & 13.6 & 18.6 & 10.6\end{array}$

$4.4 \quad 7.5$

$29.1 \quad 2.5$

$6.5 \quad 1.1$

$1.3 \quad 1.2$

$\begin{array}{ll}7.3 & 1.4\end{array}$

$2 \quad 1.8$

$12.1 \quad 1.7$

$\begin{array}{rrrrrrrrrrr}\mathrm{O} & 2 & 1 & 3.2 & 1.3 & 2.5 & 1.1 & 40.1 & 2.3 & 44.4 & 5.3 \\ \mathrm{G} & 76 & 2.6 & 1.6 & 1.5 & & & & & 34.7 & 2.3 \\ \mathrm{GO} & & & & & 12.5 & 1.5 & & & & \\ \mathrm{G} & & & 4 & 3.8 & & & & & & \\ \mathrm{GO} & & & & & 12.5 & 1.8 & 19.8 & 1.7 & & \\ \mathrm{G} & & & & & & & 80.2 & 3.1 & 1.6 & 1 \\ \mathrm{G} & & & 0.8 & 3 & & & & & & \\ \mathrm{G} & 2 & 1 & & & & & & & & \\ \mathrm{G} & & & 3.2 & 1 & & & 10.5 & 1 & & \\ \mathrm{G} & & & & & & & & & 34.7 & 2.3 \\ \mathrm{G} & & & & & & & & & \end{array}$

M

$\begin{array}{llll}0.3 & 1 & 0.8 & 1\end{array}$

HIRUDINEA

Piscicolidae gen. sp.

$0.8 \quad 1$

$2.4 \quad 1$

Loc: location in host; G: gills; M: mouth; I: intestine; CC: coelomic cavity; O: operculum; P: prevalence; MI: mean intensity. 
Host sex does not affect $\mathrm{H}$ and J' (Mann Whitney "U" test, Table II) in all host species, thus analyses were performed on the entire sample for each species. The total number of parasitic species were similar in all five host species but the number of species per fish differed significantly between hosts species (Table III) as indicated by the Kruskal-Wallis test (K-W statistics $=322.65$, $\mathrm{DF}=4, \mathrm{P}<0.001)$. The total number of parasite species and number of species per fish are not affected by sample size $(r=0.54$ and 0.62 , respectively, $\mathrm{GL}=3,0.5>\mathrm{P}>0.2$ ). Moreover, sample size (50 or more specimens for each fish species) ensured that species were not missed (Gregory \& Blackburn 1991)

The main characteristics of the parasite community of the sciaenids studied is the strong dominance of ectoparasites (Polyonchoinean monogenea in four host species and copepods in the remaining) at both qualitative and quantitative levels $(75.6 \%$ of the species and $94.4 \%$ of the individuals are ectoparasites) (Table IV). The diversity of ectoparasites (14 species of Monogenea and 11 species of Copepoda) far exceeds that of the fish hosts and endoparasites.

Low values of J' (Table II) are a clear indication of the dominance of some parasitic groups, the strong dominance exhibited by the parasitic community of M. ophicephalus, S. fasciata, S. minor and $P$. peruanus being due mainly to the Polyonchoinean monogeneans. S. deliciosa is an exception to this pattern since, in this case, the community is dominated by another ectoparasitic group, the copepoda.

\section{DISCUSSION}

Studies on the diversity of parasitic community as a whole (ecto and endoparasites) in marine fishes are scarce and no suitable data at parasite infracommunity level are available, mainly due to the fact that ectoparasites and endoparasites have been considered as independent communities and not as a member of the parasitic community as a whole. [See for instance the classical studies of

\section{TABLE III}

Total number of parasitic species per infected fish and results of "a non-parametric" Tukey test

\begin{tabular}{lccc}
\hline Host & TNS & AVG & Tukey \\
\hline Menticirrhus ophicephalus & 11 & 4.2 & $\mathrm{X}$ \\
Sciaena fasciata & 10 & 4.4 & $\mathrm{X}$ \\
Paralonchurus peruanus & 12 & 3.2 & \\
Sciaena deliciosa & 11 & 2.3 & $\mathrm{X}$ \\
Stellifer minor & 12 & 2.7 & $\mathrm{X}$ \\
\hline
\end{tabular}

TNS: total number of parasitic species; AVG: average number of parasitic species per fish.

\section{TABLE IV}

Total number of parasitic species and individuals found in the five scienids

\begin{tabular}{lcc}
\hline & Ectoparasites & Endoparasites \\
\hline Species & 27 & 10 \\
Individuals & 79431 & 3625 \\
\hline
\end{tabular}

Holmes (1990), Kennedy and Williams (1989) dealing with endohelminth communities, or those of Rohde (1993) on ectoparasites].

Thoney (1991) analyzed the parasite community of two juvenile sciaenids from the Atlantic coast of North America. The main differences between his and our data relate to the impoverished parasite fauna of our material, especially with regard to endohelminths. Thoney (1991) found 21 and 19 parasitic species in the two fishes studied and at least eight species were common to both sciaenids. Interestingly, in Thoney's material, the only core species was a generalist trematode as in our material. H. fasciata (see also Oliva \& Muñoz 1985, Luque \& Oliva 1993b) was present in four sciaenids but as a core species in only one. The sciaenids analyzed by Thoney (1991) harboured 10 species of digenean. Campos and Carbonell (1994) studied two species of labrids which were parasitized by 11 species of digenean. Recently, Luque et al. (1996) studied two haemulids from

TABLE II

Mean value of diversity $(\mathrm{H})$ and evenness $\left(\mathrm{J}^{\prime}\right)$ according the sex of the fish host

\begin{tabular}{lcccccc}
\hline & \multicolumn{3}{c}{$\mathrm{H}$} & & & $\mathrm{J}$ \\
\hline & $\mathrm{M}$ & $\mathrm{F}$ & $\mathrm{P}$ & $\mathrm{M}$ & $\mathrm{F}$ & $\mathrm{P}$ \\
\hline Menticirrhus ophicephalus & 0.148 & 0.151 & 0.808 & 0.272 & 0.247 & 0.387 \\
Paralonchurus peruanus & 0.271 & 0.308 & 0.067 & 0.621 & 0.636 & 0.941 \\
Sciaena deliciosa & 0.258 & 0.247 & 0.759 & 0.725 & 0.720 & 0.908 \\
Sciaena fasciata & 0.300 & 0.311 & 0.727 & 0.483 & 0.493 & 0.861 \\
Stelifer minor & 0.104 & 0.087 & 0.158 & 0.253 & 0.206 & 0.064 \\
\hline
\end{tabular}

M: male; F: female; P: probability of the $\mathrm{c}^{2}$ approximation to Mann-Whitney U test. 
the Brazilian coast, each species of which was infected by seven species of digenean, five of which were common to both hosts. In a similar way, Takemoto et al. (1996), found five species of digenean in three species of Oligoplites, and four were common to the three host species. In contrast, we found just one species of digenean in more than 900 host belonging to five different but related species.

The dominance of ectoparasites and the scarcity of endoparasitic fauna is characteristic of our material. A similar pattern (an impoverished endoparasitic fauna at both qualitative and quantitative levels) has been found in the neritopelagic jack mackerel Trachurus murphyi from northern Chile (Oliva 1994). Although Oliva's sample size was relatively small (78 fishes), new data set (unpublished) (over 3000 fishes analyzed from Paita-Perú to Talcahuano-Chile in a latitudinal gradient of ca. $24^{\circ}$ ) shows the same pattern, an almost absence of adult endohelminths. A similar picture occurs in the case of the flatfish Paralichthys adspersus from northern Chile (Oliva et al. 1996), where three of 22 metazoan species were adult endohelminths and 11 were larval endohelminths.

The presence of a rich endoparasitic fauna in marine fishes from colder waters not influenced by an upwelling system may be a constant. The data of Holmes (1990) from off the Vancouver coast, showed the presence of 27 endohelminth species in 88 Sebastes nebulosus, and Arthur and Albert (1994) demonstrated the presence of 37 endohelminth (plus four metazoan ectoparasites) in the Greenland halibut Reinhardtius hippoglossoides. In our material, however, the bulk of the communities are ectoparasites, represented by monogeneans in four hosts species and copepods in one.

Since the pioneering paper of Polyanski (1961) on the ecology of fish parasites, physical and chemical factors are known to be important factors affecting the distribution patterns of parasites in their macrohabitat. Additionally, zoogeographical consideration may be responsible for restricted macrohabitat extension (Font \& Tate 1994, Oliva 1994). Rohde's postulates (1993) of time hypothesis, age and area of the oceans, indicate that the richest parasitic fauna (monogenean) should be observed in fishes of the Pacific, rather than the Atlantic Oceans. Rohde's hypothesis applies to monogeneans but fails when other parasitic groups (mainly endohelminth) are considered, at least for the Peruvian Faunistic Province. The Peruvian Faunistic Province includes the central and northern Chilean coast and the southern and central Peruvian coast. This zone is characterized by an upwelling system that defines a very productive ecosystem, which supports one of the most important fisheries of the world. Additionally, this zone is aperiodically affected by ENSO (El Niño Southern Oscillation) phenomena, which dramatically alters the structure of the ecosystem, both pelagic and the benthos (Rasmusson 1984, Rodriguez et al. 1991).

Two components are distinguished in our data. First, the ectoparasites that are dominated by monogeneans. According to Rohde (1993), fishes from lower latitude harbour a richer monogenean fauna than those of higher latitudes. Sciaenids are fishes of tropical origin and 46 species are known from the Peruvian coast. However, only 11 of these invade the Peruvian Faunistic Province, (at least as south as Callao, Perú $12^{\circ} \mathrm{S}$ ); the remaining are proper to the northern Peruvian coast (Chirichigno 1980) which belongs to the Panamanian Faunistic Province. Ten species of sciaenids have been registered in the Chilean continental coast (Kong \& Valdes 1990), five (Cilus gilberti, Cynoscion analis, M. ophicephalus, S. deliciosa and $S$. fasciata) are common in the northern and central Chilean coasts, the presence of three species (Larimus pacificus, P. dumerilii and Umbrina xanti), is closely associated with the ENSO phenomena, $P$. peruanus reaches just the northern limit of Chile (Kong \& Bolados 1987) and Micropogonias furnieri is a common species in the Caribean and Atlantic coasts of South America and south and central Chile but absent in northern Chile and Perú, certainly, this sciaenids is an Atlantic invader. Geographical distribution patterns of sciaenids shows their tropical origin and the invasion and colonization of the Pacific coast of South America. The rich monogenean fauna of sciaenids from central Perú may be the result of the invasion of monogeneans in conjunction with their host, along the Pacific coast of South America. Polyonchoinean seems to be unable to invades southern latitude, because no polyonchoinean monogeneans has been found in sciaenid from northern Chile (Oliva unpublished). Moreover, no polyonchoinean has been described and/or registered to date, in marine fishes from Chile. Oligonchoinean parasitic in sciaenids are able to invade at least as far south as Talcahuano, where Hargicotyle concepcionensis, and Neobivaginopsis sciaenae have been described (Villalba 1987, Oliva \& Luque 1995) as a gill parasite of S. deliciosa. Absence of the second component, namely the trophically transmitted parasites, must be a consequence of the characteristics of the environment defined by the coastal waters of this zoogeographical province. Luque et al. (1996) suggest an impact of oceanographic processes on structure of the parasite fauna of marine fishes, specifically 
digeneans. As pointed out, (see above) oceanographic processes such as upwelling and the ENSO phenomena, are characteristics of this zone. Despite the high productivity of this ecosystem, stability is low because of the "production pulse" that characterizes this habitat. The pelagic productivity in the Peruvian faunistic province is upheld, apparently, mainly by euphausids and engraulids (Alheit \& Bernal 1993). Unfortunately, no accurate studies at the community level of pelagic and benthonic communities are available for this area. The role of zooplancton and benthos in the transmision of marine parasites is a well known process (Marcogliese 1995, Jackson et al. 1997). Thus, a low diversity of the pelagic and benthic system can explain the scarce endohelminth fauna of marine fishes from this zone.

\section{REFERENCES}

Alheit J, Bernal P 1993. Effects of physical and biological changes on the biomass yield of the Humboldt Current System, p. 53-68. In K Sherman, LM Alexander, BD Gold (eds), Large Marine Ecosystems V: Stress, Mitigation and Sustainibility, American Association for the Advancement of Sciences, Washington.

Arthur JR, Albert E 1994. A survey of the parasites of Greenland halibut (Reinhardtius hippoglossoides) caught off Atlantic Canada, with notes on their zoogeography in this fish. Can J Zool 72: 765-778.

Campos A, Carbonell E 1994. Parasite community diversity in two Mediterranean Labrid fishes Symphodus tinca and Labrus merula. J Fish Biol 44: 409-413.

Chirichigno N 1980. Clave para identificar los peces marinos del Perú. Informe Instituto del Mar del Perú Callao (Perú) No. 44, 387 pp.

Cloutman DG 1975. Parasite community structure of largemouth bass, warmouth, and blue gill in Lake Fort Smith, Arkansas. Trans Amer Fish Soc 104: 277283.

Font WF, Tate DC 1994. Helminth parasites of native Hawaiian freshwater fishes: An example of extreme ecological isolation. J Parasitol 80: 682-688.

Gregory RD, Blackburn TM 1991. Parasite prevalence and host sample size. Parasitol Today 7: 316-318.

Groenewold S, Berghahn R, Zander CD 1996. Parasite communities of four fish species in the Wadden Sea and the role of fish discarded by the shrimp fisheries in parasite transmission. Helgoländer Meeresunters 50: 69-85.

Holmes JC 1990. Helminth communities in marine fishes, p. 103-130. In GW Esch, AO Bush, JM Aho (eds), Parasite Communities: Patterns and Processes, Chapman and Hall, London, NY.

Jackson CJ, Marcogliese DJ, Burt MDB 1997. Role of hyperbenthic crustacea in the transmission of marine helminth parasites. Can J Fish Aquat Sci 54: 815-820.

Kennedy CR, Williams HH 1989. Helminth parasite community diversity in a marine fish Raja batis L. $J$
Fish Biol 34: 971-972.

Kennedy CR, Pojmanska T 1996. Richness and diversity of helminth parasite communities in the common carp and in three more recently introduced carp species. J Fish Biol 48: 89-100.

Kong I, Bolados A 1987. Sinopsis de peces asociados al fenómeno "El Niño" 1982-1983 en el norte de Chile. Est Oceanol 6: 25-58.

Kong I, Valdés J 1990. Sciaenidos de Chile: Análisis taxonómico y morfológico. Est Oceanol 9: 13-56.

Luque JL 1994. Dinámica poblacional y estructura de la comunidad de metazoarios parásitos de Menticirrhus ophicephalus (Pisces: Sciaenidae) en la costa peruana. Rev Biol Tropical (Costa-Rica) 42: 21-29.

Luque JL, Oliva ME 1993a. Análisis cuantitativo y estructura de la comunidad parasitaria de Paralonchurus peruanus (Osteichthyes: Sciaenidae) en la costa peruana. Parasitol al Día 17: 107-111.

Luque JL, Oliva ME 1993b. Trematodes of marine fishes from the Peruvian Faunistic Province (Perú and Chile), with description of Lecithochirium callaoensis n. sp. and new records. Rev Biol Marina (Chile) 28: 271-286.

Luque JL, Amato JFR, Takemoto RM 1996. Comparative analysis of the communities of metazoan parasites of Orthopristis ruber and Haemulon steindachneri (Osteichthyes: Haemulidae) from the southeastern Brazilian litoral. I. Structure and influence of the size and sex of the hosts. Rev Brasil Biol 56: 279-292.

Marcogliese DJ 1995. The role of zooplankton in the transmission of helminth parasites to fish. Reviews in Fish Biology and Fisheries 5: 336-371.

Molloy S, Holland C, Poole R 1995. Metazoan parasite community structure in brown trout from two lakes in western Ireland. J Helminthol 69: 237-242.

Oliva ME 1994. Parasites of the Chilean jack mackerel Trachurus symmetricus murphyi (Pisces: Carangidae). Mem Inst Oswaldo Cruz 89: 363-364.

Oliva ME, Luque JL 1995. Monogenean parasitic on marine fishes from Perú and Chile: Three new species and two new combinations. Mem Inst Oswaldo Cruz 90: 569-574.

Oliva ME, Muñoz MA 1985. Helicometra fasciata (Rudolphi, 1819) y Helicometrina nimia Linton, 1910 (Trematoda: Opecoelidae) en peces marinos de la II Región, Chile. Parasitol al Día 9: 107-111.

Oliva ME, Castro RE, Burgos R 1996. Parasites of the flatfish Paralichthys adspersus (Steindachner, 1867) (Pleuronectiformes) from northern Chile. Mem Inst Oswaldo Cruz 91: 301-306.

Oliva ME, Luque JL, Iannacone J 1990. The metazoa parasites of Stellifer minor (Tschudi, 1844): An ecological approach. Mem Inst Oswaldo Cruz 85: 271274.

Polyanski YI 1961. Ecology of parasites in marine fishes, p. 230-245. In VA Dogiel, GK Petrushevski, YI Polyanski (eds), Parasitology of Fishes, Oliver \& Boyd, Edinburg, London.

Rasmusson EM 1984. El Niño: the ocean'atmosphere connection. Oceanus 27: 4-12.

Rohde K 1993. Ecology of Marine Parasites, 2nd ed., CAB International, Bristol, 298 pp. 
Rodriguez L, Marin V, Farias M, Oyarce E 1991. Identification of an upwelling zone by remote sensing and "in situ" measurements in Mejillones del Sur bay (Antofagasta, Chile). Scientia Marina 55: 467-473.

Takemoto RM, Amato JFR, Luque JL 1996. Comparative analysis of the metazoan parasite communities of leatherjackets, Oligoplites palometa, O. saurus and $O$. saliens (Osteichthyes: Carangidae) from Sepetiba bay, Rio de Janeiro, Brazil. Rev Brasil Biol 56: 639-650.

Thoney DA 1991. Population dynamics and community analysis of the parasite fauna of juvenile spot Leiostomus xanthurus (Lacepede), and Atlantic croacker Micropogonias undulatus (Linnaeus), (Sciaenidae) in two estuaries along the middle Atlantic coast of the United States. J Fish Biol 39: 515 534.

Villalba C 1987. Nuevas especies de monogenea en peces marinos de Chile. Parasitol al Día 11: 141-148.

Wilkinson L 1990. SYSTAT: The System for Statistics, Evanston, II SYSTAT Inc., 560 pp.

Zar HJ 1984. Biostatistical Analysis, 2nd ed., Prentice Hall, Upper Saddle River, 662 pp. 